\title{
MARKETING STRATEGIC PLANNING: EVENT AS MARKETING STRATEGY IN A COMMERCIAL CENTER CASE STUDY
}

\author{
Isabel Cristina Almeida de Sousa ${ }^{a}$; \\ Kléuvia Macedo Oliveira Limab; \\ Renata Patrícia Müller Marquesc; \\ Carla Simone Castrod; \\ Luiz Daniel Muniz Junqueirae
}

\begin{abstract}
The overall objective of this study was to analyze the event as a marketing strategy in a commercial center. As specific objectives, we seek to understand events as a marketing strategy using case study and bibliography review to identify the communication and marketing tools organizers use and to find out the practical procedures used by organizers. People wonder in which ways marketing managers use events as a strategy to reach the public. This research has a qualitative, exploratory approach and the technique used was a case study, in which an interview was conducted with open semi-structured dissertative questions. The analysis provided the perception of the importance of events as an effective marketing tool, in which the consumer's emotional, sensory, and sentimental stimulus can influence the consumption practice.
\end{abstract}

\section{Palavras-chave}

Marketing strategic planning.

Events

Commercial Centers 


\section{INTRODUCTION}

Comercial centers have increasingly sought to attract customers and make the experience of acquiring a complete and innovative product or service available to increasingly demanding and informed consumers. It is clear that over the past years there has been a significant rise in event production in commercial centers, either to attract customers, promote brands, open spaces for conviviality, present new products or services to consumers, among others. Although to reach the aim of impressing the public positively and achieve targets already set, a previous plan is needed. A good strategic marketing plan is extremely important to achieve objectives, so the use of events as strategic tools can generate a link between organizations and audiences of interest, showing its effectiveness in actual technologic, dynamic, and constant era.

This research has as objective to analyze events as a marketing strategy in commercial centers. The elaboration of strategic marketing planning is essential and it is necessary to establish goals and targets to obtain satisfactory outcomes. As specific objectives, the study aims to understand the event as a marketing strategy by case study and bibliography, identify which are the communication and marketing tools used by organizers and know practical procedures used by organizers.

The motivation to develop this research emerged from the interest in obtaining information about the subject because, according to related research in articles, scientific journals and books, it was possible to realize that the topic is still barely known and explored. From a literature survey on strategic marketing planning and events by authors such as Kotler and Keller (2012), Armstrong and Kotler (2007), Paiva and Neves (2008) and Britto and Fontes (2002), it is questioned how marketing managers use events as a strategy to reach the public.

This article presents a theoretical basis about events, marketing strategic planning and commercial centers; the methodology used was a case-study; the analyses of the results are presented in the interview applied according to indicators and variables (marketing strategy, user profile, event selection, marketing and communication strategy, communication plan and most used media, results, department for event planning, audience record and event evaluation) and presents the final considerations about the study.

\section{EVENT: CONCEPTS AND CHARAC- TERISTICS}

\section{Concepts}

Event is a concept of a broad domain, we have several authors, and with that several definitions, here are some examples:

According to Campos, Wyse, and Araújo (2000), an event comes from the eventual term, the same as casual, an event, which leaves the routine and is always programmed to gather a group of people. Corroborating, Zitta (p. 23, 2011), mentions "an event is an occurrence where several people meet with the same objectives and purposes about an activity, theme or subject". Complementing this, Cesca (p. 20, 2008), says "an event is a fact that attracts attention and can be news and, with this, make the organizer known".

Having in mind the definitions above, it is understood that the event is an episode that aims to bring together individuals with specific goals. Besides, it promotes leisure and entertainment activities, guaranteeing the public experiences, fun, and integration, generating and consolidating bonds and relationships of professional and personal character.

According to Matias (p. 6, 2001), events are like an "action of the profession through research, planning, organization, coordination, control and implementation of a project, aiming to reach its target audience with concrete measures and projected results". Fortes and Silva (2011) defend that the event should be established to the company's communication objectives, being understood as a strategy: "[...] to show, to evoke, or to represent a key attribute of the product or service. By using it, the organization has the opportunity to reinforce its commitment to its real customers and bring together its potential customers, improving its public image and reinforcing its market positioning" (FORTES E SILVA, p. 26, 2011).

To Meirelles (1999): "An institutional and promotional instrument, used in targeted communication, to create a concept and establish an image of organizations, products, services, ideas, and people, through a previously planned event, to occur in a single space of time with the approach between participants, whether physical or through technology resources" (MEIRELLES, p. 71, 1999).

Faced with these concepts, it is understood that the creation of an event generates the possibility of attracting the attention of a certain public with similar interests. This is in harmony with the statement from Britto and Sources, who say: "The event is much more than the planning, scheduling, executing and monitoring a sequence of activities aimed at a specific audience and held in an appropriate location. The event should be thought of as an economic and social activity that generates a series of benefits for entrepreneurs, the promoting city, local commerce, restaurants, hotels, and the community" (BRITTO \& FONTES, 2002). 
With that said, according to the authors mentioned above, the event is considered a strategic marketing tool, for the approach to customers, brand promotion, sale, and purchase of products. Besides, it contributes to economic development, generating jobs in different areas, security, ceremonial, communication, people management, production, scenography, among others. Events are non-personal communication channels, being a means of communication of marketing, an efficient approach, because through its effects are stimulated sensations, emotions, and feelings of consumers, being messages transmitted through fairs and exhibitions such as shows, conventions, launches, technical visits, mega-events, among others. Despite being a non-personal contact, the event can reach consumers directly (MARTINS, 2016). Kotler and Armstrong (2008) state that the events are media that transmit messages without personal contact or feedback, but affect buyers directly. Events and their experiences and advantages can be, according to Kotler and Keller (2006): "Relevant: A well-chosen event or experience can be seen as extremely relevant as the consumer becomes personally involved. II. Involving: due to the liveliness and realtime quality of the events and experiences, consumers may find them more actively engaging. III. Implicit: Events are a type of indirect, non-aggressive selling" (KOTLER AND KELLER, p. 554, 2006).

To Carneiro e Fontes (1996): "The event, considered as a promotion strategy within marketing, has analyzed the satisfaction of customers' needs and the social process of desire demand, the planning of product offers, and the management of ideas and values appropriate to the market. It is the finalization of products and the strategic management structural, functional, and marketing that presupposes the concentration in itself of marketing interaction or instigates and presents an unprecedented innovation and discussion" (CARNEIRO E FONTES, 1996).

With the statements cited, it can be understood that the event should be relevant causing identification and providing experience to the consumer, also involving due to the liveliness and real-time quality of the events and experiences, consumers may find them more actively involving and ultimately implicit because the events are a type of non-aggressive indirect sale. The event is seen as a strategy within marketing to promote brands and gain a competitive advantage in the market, where it seeks innovation and a relationship that meets customer needs.

The events are establishing themselves as an important and integrated part of tourism development and marketing strategies (GETZ, 2008). This author establishes that the term Event Tourism has been used to describe this situation, given the development of systematic marketing of special events as tourist attractions. Currently, the activities related to planning and organization of events are regulated by Law No. 11771 of Sep- tember 17, 2008, which provides on the National Tourism Policy. As a consequence of the General Tourism Law, the activities of the events sector may be performed by companies duly accredited by the Ministry of Tourism (EMBRATUR, 2019).

From the above, it is understood that the event requires a lot of knowledge and responsibility from the organizers, since, during its realization, in case something occurs that has not been planned or thought out, some flaws compromise beyond the event the image of the organizers. Therefore, the producers who work with events must have their plans well structured, to minimize the possibility of failures in the execution of their services.

\section{Characteristics}

According to the author Helen Rita Menezes Coutinho (2010) before setting goals, it is necessary to know the characteristics of the event. According to Senac (2000), the events are characterized by the following aspects: the size, the date of the event, the profile of the participants and the goals they intend to achieve, as follows:

PORT: Small - Event with up to 200 participants. Medium - Event with an estimated number of participants between 200 and 500. Large - Event with 500 participants up to 5,000. Macro or mega-event Event above 5.000.

DATE OF REALISATION: FIXED - Event with an invariable date of realization, according to the civic, religious, and other celebrations. It takes place, annually, on the same day, with a certain periodicity. MOBILE Event that always takes place, but on a variable date, according to the calendar or interests of the promoting organization. SPORATIC - Event of temporary realization, which happens due to extraordinary facts, but planned and programmed.

PROFILE OF PARTICIPANTS: GENERAL - Event organized for an open clientele, limited only according to the capacity of the location. DIRECT - Event restricted to a public that has affinities with the theme. In general, it is subdivided into diverse interest groups. SPECIFIC - Event held for an audience clearly defined by the identity of interest in the subject.

OBJECTIVES: SCIENTIFIC AND CULTURAL - The objective may be educational, political, artistic, or sporting. COMMERCIAL - The objective is to commercialize one or more products. SOCIAL - The objective can be beneficent, congregation, and integration.

Therefore, the event is every activity where a certain organization interacts with diverse or specific audiences, to promote, integrate, educate, train, or publicize. To that, the event is a marketing strategy used to attract people to the commercial center. 


\section{Strategic Marketing Planning}

Strategic planning can be conceptualized as "a management process that enables the executive to establish the direction to be followed by the company, to obtain a level of optimization in the company's relationship with its environment" (p. 32, OLIVEIRA, 1988).

Strategic planning is the basis of a company's planning. Companies usually prepare annual, long-term, and strategic plans. Annual and long-term plans deal with the company's current business and how to keep it going. In return, a strategic marketing plan involves adapting the company so that it can take advantage of the opportunities of the constantly changing environment (ARMSTRONG and KOTLER, 2007).

For Kotler (p. 63, 2012), "strategic planning is defined as the management process of developing and maintaining a reasonable match between the company's objectives and resources and market changes and opportunities. According to Armstrong and Kotler (2007), figure 1 represents the steps of strategic planning: Kotler (p. 86, 2000) states that "the strategic marketing plan sets out the general objectives and marketing strategy based on an analysis of the current situation and market opportunities.

Therefore, strategic planning can be seen as a determining tool and the organizer's starting point, which is to anticipate what should be defined as mission, objectives and goals, business portfolio development and marketing planning, and other strategies. The definition of the strategies will help to put into practice the execution of the objectives and the survival of the company. The purpose of the planning is to adopt clear and objective measures for the conduction of attitudes towards its plan, increasing the probability that, at the time of realization, the event will occur as planned.

Marketing plays a fundamental role in the strategic planning of a company in several ways. First, it provides the guiding philosophy of marketing, which suggests that the company's strategy should revolve around building profitable relationships with important customer groups. Second, it provides information to strategic planners by helping to identify attractive market opportunities and assessing the company's potential to take advantage of them. Finally, in individual business units, it develops strategies to achieve the unit's objectives. Once these objectives are established, the task of marketing is to help the unit execute them profitably (KOTLER, 2007).

Perhaps the simplest definition of marketing is this: marketing is managing profitable customer relationships. "The two main objectives are to attract new customers, promising them superior value, and to maintain and cultivate current customers, providing them with satisfaction" (ARMSTRONG and KOTLER, p.3, 2007).

The American Marketing Association proposes the following definition: "Marketing is the activity, knowledge pool and processes of creating, communicating, delivering and exchanging offers that have value for consumers, customers, partners and society as a whole" (KOTLER and KELLER, p. 3, 2012).

Marketing is an organizational function and set of processes designed to create, communicate and deliver value to customers and to manage relationships with them in a way that benefits the organization and its stakeholders (KOTLER and KELLER, p. 27, 2012).

Because of this, the function of marketing more than any other in the business is to deal with customers. Therefore, marketing can be seen as a company function and as a social process in which marketing professionals are skilled at managing demand, seeking to influence the level, seasonality, and composition for goods, services, events, experiences, people, places, properties, organizations, information, and ideas. Marketing, generally speaking, is a process aimed at satisfying the parties who carry out exchanges.

To meet the selected customer segment offering value

Figure 01 - Steps of strategic planning

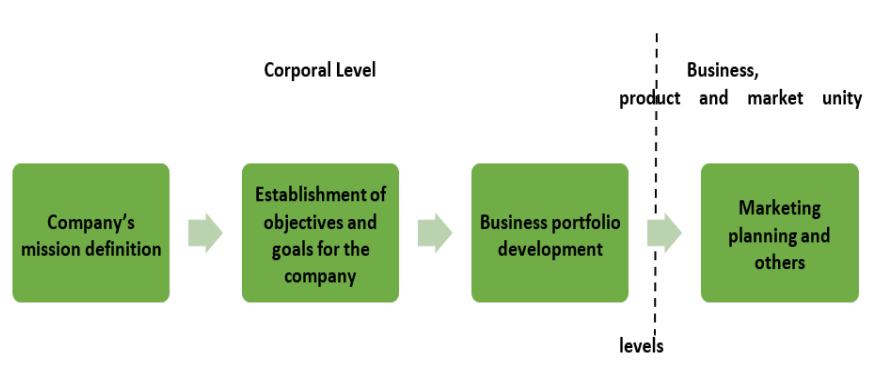

Source: Armstrong e Kotler (2007)

in the exchange, the company or the sector must adapt its plans and the variables of the marketing mix. The marketing mix, in turn, can be defined as: "a set of marketing tools that the company uses to pursue its marketing objectives in the target market" (KOTLER, 2000). The 4P's are also called controllable marketing variables that the company uses to achieve its objectives. They are product, price, square, and promotion (figure 2):

Therefore, due to the evolution of marketing management, a new concept of the 4P's already existed, forming a more modern composition, which involves the realities of current marketing: people, processes, programs, and performance.

"One of the main contributions of modern marketing is to help companies realize the importance of changing the focus of their product organization to market and customers. (KOTLER, p. 12, 2006). Figure 3 shows a comparison of the 4P's evolution: 
For Armstrong and Kotler (2007), strategic planning defines the company's mission and overall objectives. The activities and role of marketing in the company are shown in figure 4, which summarizes the main activities involved in managing a marketing strategy and marketing mix.

Guided by the marketing strategy, the company develops an integrated marketing mix composed of factors under its control, product, price, square, and promotion (the 4Ps). To find the best mix and the best marketing strategy, the company engages in marketing analysis, planning, implementation, and control. Through these activities, it observes and adapts itself to the participants and forces of the marketing environment (ARMSTRONG AND KOTLER 2007).

Consumers are at the center of everything. The goal is to create value for the customer and build profitable and strong relationships with him. The marketing logic by which the company hopes to create this value for the customer and achieve these profitable goals. The company decides which customers to serve (segmentation and target definition) and how to do it (differentiation and positioning). It identifies the total market, then divides it into smaller segments, selects the most promising ones, and turns to customer service and satisfaction in these segments (KOTLER 2007). From the perspectives presented in the figure, the main tasks for an effective marketing strategy management are the development of value and connection with customers, market segmentation, target determination, building strong brands, marketing planning, delivery and communication, the main focus is the customer, everything revolves around this aspect of satisfying their needs, always seeking innovation and experience to achieve long-term growth.

\section{COMMERCIAL CENTERS}

Commercial Center is a retail development integrated into a building or contiguous buildings, planned, built and managed as a single entity, comprising retail units and common areas, with a minimum of $500 \mathrm{~m} 2$ of Gross Lettable Area (GLA) and 12 stores (ASSOCIAÇÃO PORTUGUESA DE CENTROS COMERCIAIS, 2005).

Shopping centers are adding new values and experiences to their target public, where, in addition to being a place to shop, they are also becoming a center for leisure, entertainment, and service provision. This expansion is being driven, on the one hand, by the need to create differentials to increase its competitiveness concerning e-commerce and, on the other, to meet society's growing demand for this type of activity. With the change of the consumer, the shopping center is increasingly molding itself to a more imperative, crea- tive, fun environment, the offers are personalized directed to the public to propose a remarkable experience.

They tend to become a great coexistence center, in which people will attend not only to buy products but also to feed themselves, have fun and solve small everyday problems (BLOCH; RIDGWAY and DAWSON,

Figure 02 - The 4Ps of the marketing mix

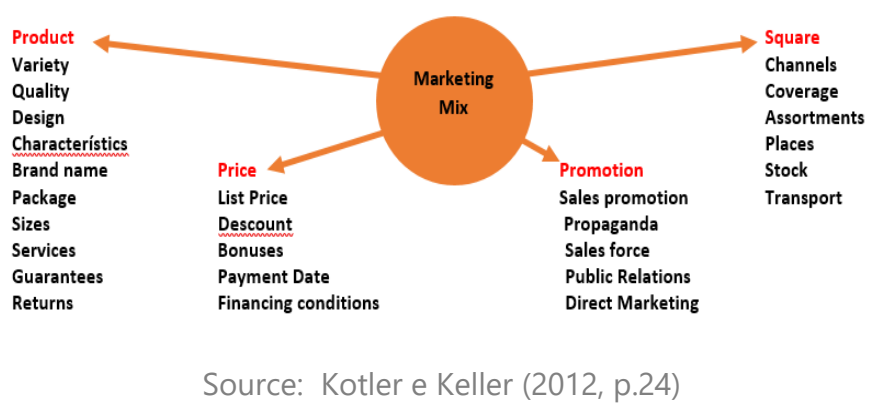

1994). Thus, a place where consumers will be able to find solutions for all their needs, including social interaction.

In this way, these centers have become a point of reference for shopping experiences and coexistence. It has become an increasingly common program, especially among teenagers, to walk in shopping malls on weekends, an activity that sometimes also includes shopping. The term experiential marketing has been used by several authors (SCHMITT, 1999; PETKUS Jr., 2004) to designate the creation of experiences for consumers.

The expanded function of the shopping mall, shopping,

Figure 03 - Marketing management development

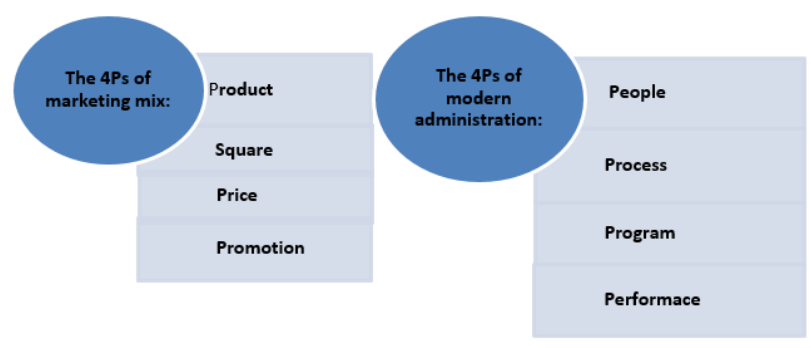

Source: Kotler e Keller (2012, p.24)

and coexistence center requires the development of four dominant attributes for the formation of its brand (SIT, MERRILEES, and BIRCH, 2003). They are the following in table 1 :

The authors also indicate three complementary critical factors for the image of a shopping center. They are entertainment, food, and security. The entertainment involves a wide range of activities offered by the shopping center, aiming at providing leisure and fun to its visitors. The most commonly found activities are cinemas, electronic games, exhibitions, shows, recreational activities, and courses. The food courts are recurrent in shopping centers and offer varied food, however, pre- 
dominantly of the fast-food type. Some establishments are trying to differentiate themselves in this respect, also offering a la carte restaurant options. Compared to other public places in a large city, shopping centers can be considered safe places, both concerning shopping (guarantees, quality, forms of payment) and urban violence (robberies, kidnappings, etc.). This aspect tends to be increasingly significant as a competitive advantage, since the issue of urban security is an item highly valued by consumers, especially in large urban centers (SIT, MERRILEES, and BIRCH, 2003).

The secret to a shopping center's competitiveness

Figure 04 - The 4Ps of the marketing mix

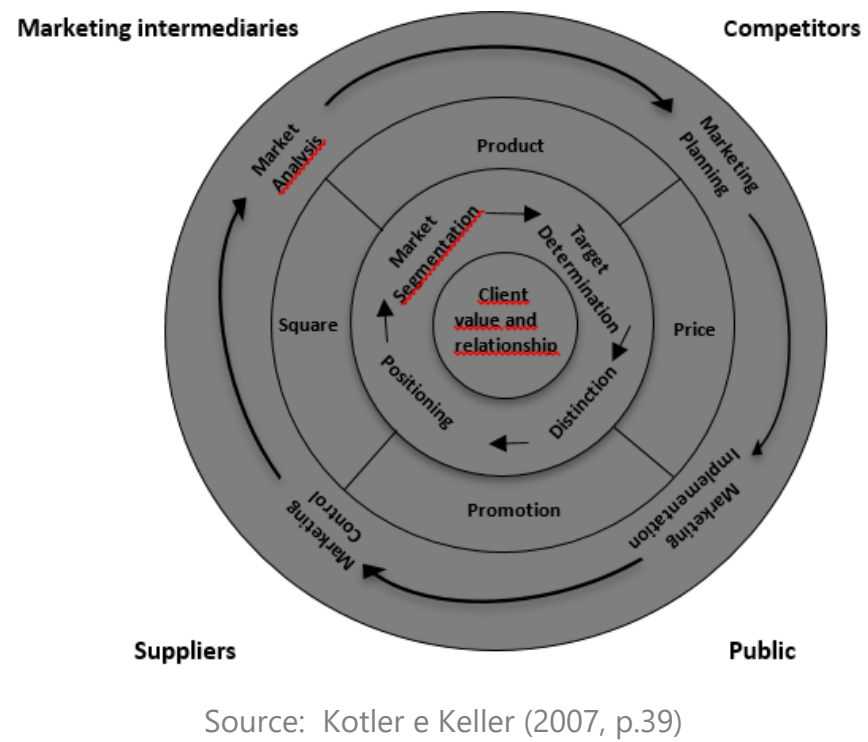

seems to lie in its ability to integrate the mix of products and services with leisure and entertainment activities in a harmonious way. The combination (PARSONS, 2003) of sales and entertainment promotions is a strong alternative to stimulate visitation and shopping expenses. Simple discount promotions tend to become more and more harmless as consumers do not visit these locations exclusively for shopping.

Because of this, it is understood that, in addition to shopping, food court, services, conveniences, creative and entertaining multipurpose space, the shopping center is increasingly meeting the events, which generate content, entertainment, experiences, purposes, for a relational connection, increasingly strong between the shopping center and the customer.

\section{METHODOLOGICAL PROCEDU- RES}

This research has a qualitative approach, of exploratory character and has a technique the case study. According to Triviños (1987), in qualitative research, the na- tural environment is the direct source of data and the researcher is the key instrument. The exploratory character allows the familiarization of the problem to make it explicit. In this type of research it is very common to use data and secondary sources (DENCKER, 1998). For Fonseca (p. 33, 2002) "A case study can be characterized as a study of a well-defined entity such as a program, an institution, an educational system, a person, or a social unit".

Preliminarily, contact was made with the shopping center to see who could contribute to the research. The data collection was carried out through an open semistructured interview, on the google forms platform, with the person responsible for the marketing department of the shopping center.

The analysis of content is carried out through the indicators: marketing strategy,

the profile of the frequenter, selection of events, record audience, communication, results, and evaluation. From these indicators it was possible to systematize the information and seek the inference of knowledge related to the theories.

\section{DISCUSSION AND RESULTS}

The interview was composed of dissertation questions that have as the objective of the sample to produce indepth and illustrative information of the events as a marketing strategy carried out in the shopping center. The interviewee is the marketing manager of a Shopping Center in Brasília/DF.

About the indicator "Marketing Strategy" Kotler and Keller (2006) says that, the event should be relevant, causing identification and providing experience to the consumer. It should also be engaging, due to the liveliness and real-time quality of the events and experiences. Consumers may find them more actively engaging and ultimately implicit, as the events are a nonaggressive type of indirect selling.

For the Interviewee "Events are strategies to bring customers closer to brands" (INTERVIEWEE, 2019). Given the above, it is analyzed that the use of the event as a marketing strategy offers an opportunity to publicize the product or service, achieving the sales objective.

Comparing Kotler and Keller's theory with the response to the interviewee's indicator in a qualitative way, it can be said that the marketing strategy used is effective, because to achieve the sales objective it is necessary to win the customer allowing experience and innovation. According to Kotler regarding the target audience (2003, apud, MAZZETTO, 2014), the process of choice must start with a well-defined target audience in mind, possible buyers of the company's products, current users, people who decide or influence, individuals, groups, specific audiences or the general public. 
Table 01 - Dominant attributes for image formation

\begin{tabular}{l|l}
\hline Merchandising & $\begin{array}{l}\text { It involves the exhibition of goods, high- } \\
\text { lighting variety, quality, style of products } \\
\text { available for sale. It is directly related to } \\
\text { the main activity of the establishment, } \\
\text { which is the marketing of products and } \\
\text { services; }\end{array}$ \\
\hline Accessibility & $\begin{array}{l}\text { It refers to the ease of access, both exter- } \\
\text { nal (to get to the site) and internal (access } \\
\text { to the parking lot, the shops, the width of } \\
\text { the aisles, etc.). This aspect is a relevant } \\
\text { factor in the consumer's decision for a } \\
\text { store; }\end{array}$ \\
\hline Services & $\begin{array}{l}\text { They include everything from the quality } \\
\text { of service in stores to complementary ser- } \\
\text { vices such as toilets, wardrobes, and infir- } \\
\text { maries. Finally, aspects that can ensure } \\
\text { that the experience lived by the consumer } \\
\text { is as favorable as possible; }\end{array}$ \\
\hline Atmosphere & $\begin{array}{l}\text { It is related to the environmental condi- } \\
\text { tions that cause a sense of well-being in } \\
\text { consumers, facilitating the process of posi- } \\
\text { tive experience. The atmosphere involves } \\
\text { aspects such as environment, decoration, } \\
\text { color, music, and layout. }\end{array}$ \\
\hline
\end{tabular}

For the interviewee, the profile of the target audience or the "Attendee Profile" was defined through marketing studies as well as the selection of the typology for the event at the shopping center. "Profile: classes $A / B=$ $81 \%$, cassette $C=19 \%$ Yes, we have marketing studies

Source: IKEDA, CRESCITELLI and MIOLA (2005)

that, in addition to other information, indicate the psychological profile and radius of the neighborhood of our consumers" (INTERVIEWEE, 2019).

Analyzing the interviewee's information in a qualitative approach, the answer obtained is in line with Kotler's theory, since it is necessary to establish a target audience according to the typology of the event or "Selection of Events" according to the research indicator.

The indicators "Communication and Marketing Plan" according to Ogden and Crescitelli (p. 3, 2007) "It is important to emphasize that without a marketing plan one cannot establish an effective communication plan, because many of the assumptions adopted in communication planning are defined in the marketing plan".

According to the interviewee's answer "The plan is built after the briefing that is directed to the communication agency and press office. About the means used, as I said, will depend on the greatness of the event. We can carry out planning that involves VTs (films), publicity in front lights, (outdoor media), ads in newspapers (print media), indoor media (using spaces in the mall itself), and online as e-mail marketing, purchase of spaces (banners) in portals of news and entertainment, as well as posts in our social networks". It demonstrates the elaboration of a communication and marketing plan, being necessary the use of technological tools, which contribute to the reach of the divulgation, be it in on or offline media, and the importance of fundraising for such divulgations, taking into account the size of the event.

The importance of the communication and marketing plan was identified because according to Ogden and Crescitelli's (2007) theory, one plan depends on the other to be well-executed and obtain the expected results. The strategic alignment for the event can contribute to greater control of possible problems and situations that may occur. Good communication between those who are part of the organization will bring greater security and comfort to the participants.

The "Evaluation" indicator for Ogden and Crescitelli ( $p$. 9 , 2007) "Several activities are developed to help the marketing manager control and evaluate the effectiveness of a campaign, for example, focus group surveys, feedback spreadsheets and quantifiable statistics".

The manager describes that the application of qualitative satisfying research is a form of evaluation and control, and it is possible to analyze the flow of visitors, identify failures, and weigh results. "We carry out satisfaction surveys among event attendees, analyze the flow it has generated, survey satisfaction and results among tenants and analyze social networks to see what people are commenting on the event" (INTERVIEWEE, 2019).

Opinion polls and evaluation of the event are important to the process of continuous improvement in the service provided, and it is extremely important to evaluate the results to take measures that improve the customer experience.

This research was able to understand the importance of the event as strategic marketing planning to obtain a competitive advantage in the market, through bibliographic analysis and case study. The bibliographic analysis provided the perception of the relevance of the event as an effective marketing tool, in which the consumer's emotional, sensory, and sentimental stimulus can influence the consumption practice.

The results obtained through the case study demonstrate that the events contribute significantly to the achievement of the marketing objective. Technology has transformed the profile of consumers even from different classes, where most have access to communication media being the internet and social media the most common. Such transformation has affected the way shopping malls take steps to bring in the public. Shopping centers can no longer be monotonous in the face of changing customer profiles, making it essential to offer new experiences, entertainment, leisure, and fun as a determining purchasing factor for companies to leverage their business. Therefore, nowadays, within marketing strategies, event marketing is the fastest- 
growing promotional modality.

\section{CONCLUSIONS}

The objective of this article was to analyze the event as a marketing strategy in a shopping center. As a result, it was observed that the use of the event is an effective tool in the marketing planning of a company, which aims to satisfy the consumer and make a profit.

It was concluded that it was possible to understand the use of the event as a marketing strategy as a means of bringing innovation and satisfactory experiences to customers.

We identified the communication and marketing tools that the organizer uses in advertising, which are: web-

Table 02 - Results' Analysis

\begin{tabular}{|c|c|}
\hline $\begin{array}{l}\text { VARIABLE } \\
\text { INDICATORS }\end{array}$ & INTERVIEWEE'S information \\
\hline $\begin{array}{l}\text { MARKETING } \\
\text { STRATEGIES }\end{array}$ & $\begin{array}{l}\text { Yes. Events are strategies to bring cus- } \\
\text { tomers closer to brands. }\end{array}$ \\
\hline USER PROFILE & $\begin{array}{l}\text { Profile: classes } A / B=81 \% \text {, cassette } C= \\
19 \% \\
\text { Yes, we have market studies that, in addi- } \\
\text { tion to other information, indicate the } \\
\text { psychological profile and radius of the } \\
\text { neighborhood of our consumers. }\end{array}$ \\
\hline $\begin{array}{l}\text { EVENTS } \\
\text { SELECTION }\end{array}$ & $\begin{array}{l}\text { We always select events that have an } \\
\text { affinity with our target audience. }\end{array}$ \\
\hline $\begin{array}{l}\text { MARKETING } \\
\text { AND } \\
\text { COMMUNICA- } \\
\text { TION } \\
\text { STRATEGIES }\end{array}$ & $\begin{array}{l}\text { For major events, such as this decoration } \\
\text { show, we use a more comprehensive } \\
\text { communication planning with off and } \\
\text { online campaigns, in addition to activat- } \\
\text { ing our press office to produce spontane- } \\
\text { ous media in various media outlets. }\end{array}$ \\
\hline $\begin{array}{l}\text { THE COMMU- } \\
\text { NICATION } \\
\text { PLAN AND } \\
\text { MOST USED } \\
\text { MEANS }\end{array}$ & $\begin{array}{l}\text { The plan is built after the briefing that is } \\
\text { directed to the communication agency } \\
\text { and press office. About the means used, } \\
\text { as I said, will depend on the greatness of } \\
\text { the event. We can carry out planning that } \\
\text { involves VTs (films), publicity in front } \\
\text { lights, (outdoor media), ads in newspa- } \\
\text { pers (print media), indoor media (using } \\
\text { spaces in the mall itself), and online as e- } \\
\text { mail marketing, purchase of spaces } \\
\text { (banners) in news and entertainment por- } \\
\text { tals, as well as posts in our social net- } \\
\text { works. However, if the event does not } \\
\text { have a certain "weight", we do not have } \\
\text { the money, and we see that it will not be } \\
\text { a great generator of flow, }\end{array}$ \\
\hline
\end{tabular}

a great generator of flow,

\begin{tabular}{|c|c|}
\hline $\begin{array}{l}\text { THE COM- } \\
\text { MUNICATIO } \\
\text { N PLAN AND } \\
\text { MOST USED } \\
\text { MEANS }\end{array}$ & $\begin{array}{l}\text { we can plan something more simplistic } \\
\text { and restrict ourselves only to low-cost } \\
\text { actions such as press relations, social me- } \\
\text { dia at the mall and some pieces of internal } \\
\text { disclosure in the evil of the mall (indoor } \\
\text { media). }\end{array}$ \\
\hline RESULTS & $\begin{array}{l}\text { The primary result expected from an } \\
\text { event is flow generation. Flow is a religion } \\
\text { in shopping centers. Without flow, no } \\
\text { shopping mall venture survives. We must } \\
\text { always be careful to analyze whether this } \\
\text { flow has an affinity with the mall's public } \\
\text { and also whether it is a qualitative flow } \\
\text { that can generate results in future sales. }\end{array}$ \\
\hline $\begin{array}{l}\text { EVENTS } \\
\text { PLANNING } \\
\text { DEPART- } \\
\text { MENT }\end{array}$ & $\begin{array}{l}\text { The shopping center marketing depart- } \\
\text { ment is in charge of this function. In } 14 \\
\text { years working in the shopping mall sector, } \\
\text { I have not known, until now, any enter- } \\
\text { prise that had an internal/organic depart- } \\
\text { ment specialized only in events. }\end{array}$ \\
\hline $\begin{array}{l}\text { RECORD } \\
\text { ATTEND- } \\
\text { ANCE }\end{array}$ & $\begin{array}{l}\text { We held an event at the mall that was a } \\
\text { decoration show (Morar Mais Por Menos) } \\
\text { that lasted } 20 \text { days. During this period } \\
\text { more than } 40 \text { thousand people visited the } \\
\text { mall is the event. }\end{array}$ \\
\hline $\begin{array}{l}\text { EVENT } \\
\text { EVALUATION }\end{array}$ & $\begin{array}{l}\text { We carry out satisfaction surveys among } \\
\text { event attendees, analyze the flow it has } \\
\text { generated (digital flow counters), survey } \\
\text { satisfaction and results among tenants and } \\
\text { analyze social networks to see what peo- } \\
\text { ple are commenting on the event. }\end{array}$ \\
\hline
\end{tabular}

Source: elaborated by the authors

sites, social networks, drives, sponsored posts, promotions, e-mail marketing, out of home media like TVs and billboards. The practical procedure begins in the relationship with stakeholders, including, from pre to post-production, through face-to-face meetings to align the stages of the event, insertion and disclosure, brand activation, and delivery of reports. Organizers use events as a marketing tool to attract their clients and achieve their goals.

There were difficulties in obtaining information on the subject, which is very restricted. Still at the beginning of the survey, there was no feedback from the people who received the questionnaire.

By analyzing the event at the mall, we identify how important it becomes for strategic marketing planning and how focused its positioning is on the target audi- 
ence. The shopping center in its strategic planning, continuously reviews its products with those of its competitors, since it is necessary to constantly update itself to follow the transformations in the options offered and in the choices made by consumers.

Therefore, with the analysis, it was found that the shopping center needs an events department for its best planning, with qualified and specialized professionals in this area, considering the importance that events bring to these centers.

Finally, it is highlighted the continuous need for the improvement of marketing actions in the events sector, aiming at meeting the expectations of a promising and profitable market, as well as the improvement in the quality of the services offered. .

\section{REFERENCES}

Akemi I. A., Crescitelli, E., Miola, R. (2005). Marketing vivencial: o caso de eventos musicais no shopping. Revista de Administração Mackenzie, RAM vol. 6, núm. 3, São Paulo.

Britto, J., Fontes, n. (2002) Estratégias para eventos: uma ótica do marketing e do turismo. São Paulo, SP: Aleph.

Bloch, P. H., Ridgway, N. M. Dawson, S. A. (1994). The shopping mall as consumer habitat. Journal of Retailing, v. 70, $n .1$, p. 23-42, spring.

Belch G. E., Belch M. A. (2008). Propaganda e Promoção. Uma Perspectiva da Comunicação Integrada de Marketing. 7a ed. Editora: AMGH.

Campos, L. C., Wyse, N., Araújo, M. L. S. (2000). Eventos: Oportunidade de novos negócios. Rio de Janeiro, RJ: Senac Nacional.

Carneiro. J. B., Fontes, N. D. (1996). Projeto especial de treinamentos - P.E. T 2. Planejamento e organização de eventos. São Paulo: Dantas Britto Projetos em Turismo e Eventos.

Cesca, C. (2008). Organização de eventos: manual para planejamento e execução. 9 ed. rev. e atual - São Paulo: Summus.

Coutinho, H. R.M. (2010). Organização de Eventos. CETAM-Manaus -AM-e-Tec-Brasil

Dencker, A. F. M. (1998). Métodos e Técnicas de Pesquisa em Turismo. São Paulo: Futura.

Fonseca, J. J. S. (2002). Metodologia da pesquisa científica. Fortaleza: UEC.

Fortes, W. G., Silva, M. B. R. (2011). Eventos: estratégias de planejamento e execução. São Paulo: Summus.

Getz, D. (2008). Event tourism: definition, evolution, and research. In: Tourism Management. Elsevier Ltda. 29 ed. 2008, p. 403 -428 .

Kotler, P., Keller, K. (2012). Administração de marketing. 14a Edição - Tradução Sônia Midori Yamamoto; revisão técnica
Edson Crescitelli. São Paulo: Pearson Education do Brasil.

Kotler, P. (2006). Marketing para o século XXI: como criar conquistar e dominar mercados. 16 ed. São Paulo: Futura.

Kotler, P., Armstrong, G. (2007). Princípios de marketing. $12^{a}$ ed. São Paulo: Pearson Prentice Hall.

Kotler, P. (2000). Administração de Marketing. 10므 Edição, $7 \underline{a}$ reimpressão -Tradução Bazán Tecnologia e Linguística; revisão técnica Arão Sapiro. São Paulo: Prentice Hall.

Matias, M. (2001). Organização de Eventos: procedimentos e técnicas. São Paulo: Manole.

Meirelles, G. F. (1999) Tudo sobre eventos. São Paulo: Editora STS.

Ogden, J. R. , Crescitelli, E. (2007). Comunicação integrada de marketing: conceitos, técnicas e práticas. $2^{\circ}$ ed. São Paulo: Pearson Prentice Hall.

Oliveira, D. P. R. (1988). Planejamento Estratégico: conceitos, metodologia e práticas. 3.ed. São Paulo: Atlas.

Parsons, A. G. (2003). Assessing the effectiveness of shopping mall promotions: customer analysis. International Journal of Retail e Distribution Management, v. 31, n. 2, p. 74-79.

Sit, J., Merrilees, B., Birch, D. (2003). Entertainment-seeking shopping centre patrons: the missing segments. International Journal of Retail \& Distribution Management, v. 31, n. 2, p. 80-95.

Schmitt, B. (1999). Experiential marketing. Journal of Marketing Management, v. 15, n. 1-3, p. 53-67.

Triviños, A. N. S. (1987). Introdução à pesquisa em ciências sociais: a pesquisa qualitativa em educação. São Paulo: Atlas.

Zitta, C. (2011). Organização de Eventos: da ideia à realidade. Brasilia, DF: Senac.

Instituto Brasileiro de Turismo - Embratur (2019). Disponível em:<http: // www.embratur.gov.br>. Acesso em: 18 out. 2019.

Associação Portuguesa de Centros Comerciais (2013). Disponível em: <apcc.pt/centroscomerciais/definições-e-tipologias/ definição-de-centro-comercial/3>. Acesso em: 10 abril 2020 
